\title{
Corela
}

Cognition, représentation, langage

$16-2 \mid 2018$

Vol. $16, n^{\circ} 2$

\section{The pronunciation of vowels with secondary stress in English}

Quentin Dabouis

\section{(2) OpenEdition}

1 Journals

Electronic version

URL: http://journals.openedition.org/corela/7153

DOI: 10.4000/corela.7153

ISSN: 1638-573X

\section{Publisher}

Cercle linguistique du Centre et de l'Ouest - CerLICO

\section{Electronic reference}

Quentin Dabouis, «The pronunciation of vowels with secondary stress in English », Corela [Online] 16-2 | 2018, Online since 18 December 2018, connection on 10 December 2020. URL : http:// journals.openedition.org/corela/7153; DOI : https://doi.org/10.4000/corela.7153

This text was automatically generated on 10 December 2020 .

\section{(c) (i) (2)(2)}

Corela - cognition, représentation, langage est mis à disposition selon les termes de la licence Creative Commons Attribution - Pas d'Utilisation Commerciale - Partage dans les Mêmes Conditions 4.0 International. 


\title{
The pronunciation of vowels with secondary stress in English
}

\author{
Quentin Dabouis
}

\section{Introduction 1}

1 Research on the pronunciation of vowels has often focused on vowels with primary stress. Vowels with secondary stress have rarely been the object of specific studies. After introducing the general framework adopted here and the proposals that have been put forward in the literature (\$1), I will establish the aims of this paper (\$2). Then, I will present the methodology used for the study of vowels with secondary stress here (\$3) before detailing the results and their interpretation (\$4).

\section{Theoretical background}

\subsection{General framework}

2 The framework adopted here is that introduced by Guierre (1979) and later developed, among others, by Fournier (1998, 2007, 2010), Deschamps (1994), Duchet (2018) and Trevian (2003). This approach aims to account for two main phenomena: stress placement and reading rules in contemporary English. Here, I shall be interested in the latter. The approach can be characterised by several theoretical assumptions: the fact that spelling ( Dabouis in preparation) or certain types of morphological structures (Dabouis 2017a; Fournier 1996) can be relevant to phonology, or the fact that there is more than a single phonology in English (Dabouis 2016: \$3.5; Fournier 2007). It is also characterised by the methodology used to study the (grapho)phonological system in English. Where most generative works in phonology are based on samples whose origin or representativeness are seldom discussed, works conducted in the Guierrian tradition have always used large corpora, most often taken from pronunciation dictionaries. 
3 Following the British tradition, three levels of stress are acknowledged. They are listed in

(1) along with the way they will be represented throughout this paper.

(1) Primary stress $/ 1 /$, ó or [']

Secondary stress $/ 2 /, \dot{\sigma}$ or $[1]$

No stress $/ 0 /, \sigma$ or []

4 The next section introduces the system of correspondences between the orthographic form and the phonological form developed in that framework.

\subsection{Vowel values}

5 When we analyse the spelling-to-sound correspondences for vowels, we observe that stressed vowels can usually have four different "values". For example, <a> can be realised as [Æ] (e.g. fat), [eI] (fate), [a:] (far) or [eə] (fare). The whole table of correspondences is shown in Table 1.

\begin{tabular}{|c|c|c|c|c|c|}
\hline$\stackrel{\mathbf{r}}{\mathbf{V}}$ & $\widetilde{\mathbf{V}}$ & Monographs & $\overline{\mathbf{V}}$ & $\overline{\mathbf{V}}^{\mathbf{r}}$ & Digraphs \\
\hline $\mathrm{r}$ vowel & $\begin{array}{c}\text { checked } \\
\text { vowel }\end{array}$ & $<\mathbf{V}>$ & $\begin{array}{c}\text { free } \\
\text { vowel }\end{array}$ & $\begin{array}{l}\text { r-coloured } \\
\text { free vowel }\end{array}$ & $<\overline{\mathbf{V V}}>$ \\
\hline$[a:]$ & [æ] & $<\mathrm{a}>$ & [eI] & [eə] & $<$ ai, ay / ei, ey> \\
\hline [3:] & {$[\mathrm{e}]$} & $<\mathrm{e}\rangle$ & [i:] & [Iә] & $<\mathrm{ea}$, ee $/ \mathrm{ie}^{* *}>$ \\
\hline$[3:]$ & {$[\mathrm{I}]$} & $<\mathrm{i}>$ & [aI] & [агә] & $<\mathrm{ie}^{*}, \mathrm{ye}>$ \\
\hline$[0:]$ & [p] & $<0>$ & {$[\partial v]$} & {$[0:]$} & $<$ oa $^{* *}$, oe $^{*>}>$ \\
\hline \multirow[t]{5}{*}[3:]{} & {$[\Lambda(v)]$} & $<\mathrm{u}>$ & [(j)u:] & [(j)və] & $<\mathrm{e}(\mathrm{a}) \mathrm{u}, \mathrm{ew} / \mathrm{ue}^{*}>$ \\
\hline & & & {$[0:]$} & {$[0:]$} & $<\mathrm{au}, \mathrm{aw}>$ \\
\hline & & & {$[\mathrm{u}:]$} & {$[0:]$} & $<\mathrm{oo}>$ \\
\hline & & & [0I] & & $<$ oi, oy $>$ \\
\hline & & & {$[\mathrm{av}]$} & [o: (avə)] & $<$ ou, ow $>$ \\
\hline
\end{tabular}

Table 1. Table of correspondences for vowels (taken from Fournier (2010: 98))

This table actually contains two tables: one for monographs and one for digraphs. Monographs normally have four different values: $r$, checked, free and r-coloured free, while digraphs only have two: free and r-coloured free. As some of the vowels are shared, both tables can be represented together by merging the overlapping parts of each table.

7 Note that these correspondences may not hold in the case of foreign words, where the principle of articulatory proximity with the vowels of the source languages sometimes overrides that of graphic analogy (Tournier 1993: 149). The main three foreign free vowels (represented as $\overline{\mathrm{V}}^{\mathrm{e}}$ ) are shown in Table $2 .^{2}$ Note that $<0>$ and $<\mathrm{u}>$ are not realized differently in foreign vocabulary. However, a few words with $<0>$ are realised as free vowels in contexts where checked vowels are expected, which could be explained by the fact that they are foreign words (see $\$ 4.1 .3$ below). 


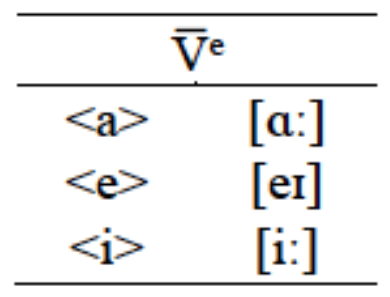

Table 2. The main foreign free vowels

8 A number of rules can be used in order to determine which value should be used for a given stressed vowel. First, I will introduce the rules which have been proposed for vowels with primary stress before turning to those with secondary stress in the next section. These rules refer mainly to the spelling of the stressed vowel, to its right-hand context and to its rank. The presentation given here follows that of Fournier $(1997,2010)$. In this approach, the rules are hierarchically ordered, and the general organisation of these rules represents the hierarchy of the parameters which determine vowel values. The first of these rules deals with vowel digraphs (represented as $\overline{\mathrm{VV}}$ ) and it states that if the vowel is a digraph, then it should be a free vowel. The fact that it is the first rule means that the value "digraph" for the parameter "nature of the vowel" dominates all the other parameters. The vowel will normally be free, even in contexts in which monographs are normally checked. This also means that, at this point, all the words in the lexicon with a digraph have been accounted for (apart from the few exceptions; e.g. head, look, cough) and that all the remaining words have a monograph. Therefore, the value "monograph" for the parameter "nature of the vowel" is neutral in the sense that it is not associated to a fixed vowel value and that it is necessary to use other parameters to determine which vowel value should be used.

The hierarchical organisation of rules is determined through the analysis of relevant cases, i.e. words which fit the structural conditions for the application of two contradictory rules. For example, one of the later rules is the " $\mathrm{C}_{2}{ }^{3}{ }^{3}$ rule, which holds that a vowel followed by two consonants should be checked (e.g. nest, custom, mystery, passion). Digraphs followed by two consonants (e.g. augment, feast, boost) are therefore relevant cases to determine the hierarchy between the rule $\overline{\mathrm{VV}} \rightarrow \overline{\mathrm{V}}$ and the rule $\mathrm{C}_{2} \rightarrow \breve{\mathrm{V}}$. The fact that these words all have free vowels shows that the former dominates the latter. Sometimes, such an analysis cannot be conducted because the rules are not contradictory, i.e. they predict the same value. For examples, it would be difficult to say whether words such as agnóstic, eccéntric, sadistic obey the $C_{2} \rightarrow \breve{V}$ or the -ic(s)\# $\rightarrow \breve{V}$ rule ${ }^{4}$, as both yield checked vowels. The answer lies in transitivity, i.e. if $A>B$ and $B>C$, then $A>C$. It can be shown that the rule $\mathrm{u} \rightarrow \overline{\mathrm{V}}$ is dominated by $\mathrm{C}_{2} \rightarrow \breve{\mathrm{V}}$, as words with $<\mathrm{u}>$ followed by $\mathrm{C}_{2}$ have checked vowels (e.g. butter, function, mustard) but that this rule dominates -ic (s)\# $\rightarrow \breve{\text { V}}$, as words in $<-u C i c(s) \#>$ have free vowels (e.g. cubic, mercuric, music). Therefore, through transitivity, we can assert that $\mathrm{C}_{2} \rightarrow \breve{\mathrm{V}}$ dominates -ic(s)\# $\rightarrow \breve{\mathrm{V}} .{ }^{5}$ Of course, this is an idealisation of how the language functions, but it is perfectly imaginable that rules conspire to produce the same result for speakers.

The rules are divided into two groups. The first group of rules deals with the stressed syllable and is shown in (2).

(2) $\overline{\mathrm{VV}} \rightarrow \overline{\mathrm{V}}$ e.g. out, wáy, néed, house, méan, fóod...

$\mathrm{C}^{0} \rightarrow \overline{\mathrm{V}}$ e.g. bé, mé, só, whý, scíence, muséum... 
$\mathrm{rC} / \mathrm{r} \# \rightarrow \breve{\mathrm{V}}$ e.g. párt, túrn, pérson / fár, prefer, guitár...

$\mathrm{C}_{2} / \mathrm{C} \# \rightarrow \breve{\mathrm{V}}$ e.g. thínk, néxt, still, sórry / lót, mán, untíl... regulating the value of vowels with secondary stress. Both acknowledge that the first group of rules and the rule $u \rightarrow \bar{V}$ applies to vowels with secondary stress as it does for those with primary stress, except -r\#, -C\# and -ic(s)\# which crucially refer to the end of the word and are therefore inapplicable. However, their analyses differ when it comes to the remaining rules.

Guierre claims that the pretonic sequence (i.e. all that precedes primary stress) behaves like the end of the word. In other words, the syllable with primary stress would be for the vowel with secondary stress what the end of the word is to the vowel with primary stress. The analyses therefore predict different applications of the rules that refer to the rank of the stressed vowel. For instance, Luick's rule applies to a vowel that is at least antepenultimate. If one considers only the pretonic sequence, that means that Luick's rule should apply only with the $/ 200(-) /{ }^{9}$ pattern, whereas if one counts from the end, it could apply with the /(-)201(-)/ pattern. As Fournier applies the rules to vowels with secondary stress in a similar fashion as to vowels with primary stress, that means that the rule of the penultimate cannot apply, as vowels with secondary stress are not normally found in the penultimate syllable. As a consequence, his analysis predicts that Luick's rule will apply to vowels with secondary stress in /\#0201(-)/. Finally, Fournier predicts that the CiV rule will apply to words in which the vowel following $<\mathrm{i}>$ or $<\mathrm{e}>$ is the last of the word (e.g. comediénne) and that, otherwise, Luick's rule will apply. Guierre predicts the CiV rule will apply regardless of what may follow the sequence of two vowels. The different predictions made by these two analyses are summed up in Table 3. 


\begin{tabular}{|c|c|c|}
\hline Structure & Guierre (1979) & Fournier (1994) \\
\hline \#201(-) & $?$ & \multirow{4}{*}{$\breve{V}$ (Luick) } \\
\hline \#2001(-) & $\overrightarrow{\mathrm{V}}$ (Luick) & \\
\hline$\# 0201(-)$ & $\overline{\mathrm{V}}$ (penultimate) & \\
\hline$(-) \dot{\sigma}\{i, e\} V C_{0}^{-}$ & \multirow{2}{*}{$\overline{\mathrm{V}}(\mathrm{CiV})$} & \\
\hline$(-) \dot{\sigma}\{i, e\} V_{0} \#$ & & $\overline{\mathrm{V}}(\mathrm{CiV})$ \\
\hline
\end{tabular}

Table 3. Values predicted by Guierre (1979) and Fournier (1994) for vowels with secondary stress

\subsubsection{Semantically transparent prefixes} deactivate, ex-actor, redo, subdomain) but also in a few constructions with bound bases (e.g. acephalous, decelerate, export). There is converging evidence that these prefixes have their own phonological domain, unlike semantically opaque prefixes. ${ }^{10}$

First, they can carry secondary stress, regardless of the stress pattern of their base. This can generate stress clashes, which are normally banned domain-internally (e.g. coáuthor, èxbóyfriend, rèdó) (J.-M. Fournier 2010: Ch. 1; Guierre 1979: 317; Trevian 2003: 160). Second, they can generate gemination when their final consonant is the same as the first consonant of their base (e.g. di[s: ]imilation, i[1:]ogical, $u[n:] a t u r a l)$ (Ben Hedia \& Plag 2017; Cruttenden 2014: 248; Fudge 1984:\$6.1; Guierre 1979: 276; Kaye 2005; Oh \& Redford 2012; Videau 2013). Third, the position of stress can be different, especially for prefixed constructions of more than two syllables in -ate, such as the examples in (4), which are taken from Raffelsiefen (1993: 119).

(4) récreate "to impart fresh life to" rè-creáte "to create again"

This difference is significant because verbs in -ate have final primary stress if they are disyllabic and antepenultimate stress if they are longer. Therefore, rè-creáte really behaves as if re- and create were independent. Finally, and crucially for this paper, monosyllabic prefixes which end with a vowel usually have a $\bar{V}$. This diverges from the behaviour of vowels in semantically opaque prefixes which normally follow general rules, such as Luick's rule, as will be seen in the next section. The difference between opaque and transparent prefixes can be seen in the examples in (5), which are taken from Raffelsiefen (1993: 118). ${ }^{11}$

(5) a. r[è]presént "to serven express or stand for"

r[è]colléct "to recall to mind"

b. r[i:]present "to present again"

r[i:]colléct "to collect again"

In the system of rules presented in $\$ 1.2$, assuming that prefixes have their own phonological domain means that the rule applying in (5b) is $\mathrm{C}^{0} \rightarrow \overline{\mathrm{V}}$, just as it does to word-final vowels (e.g. so, why, me). 


\subsubsection{Suffixed words}

According to Fournier (1994), there are two options for words suffixed with stressshifting suffixes. The value will be identical to that found in the base if the secondary stress in the derivative is on a syllable that is stressed in the base (e.g. notable $\bar{V} \rightarrow$ notability $\overline{\mathrm{V}}$ ). If the base has primary stress on its second syllable and the suffix shifts it to the third syllable, then stress preservation cannot occur (e.g. derive $\rightarrow$ dèrivátion). ${ }^{12}$ Secondary stress is then placed on the first syllable and the vowel with secondary stress should obey the same rules as non-derived words.

\section{Aims}

None of the works discussed in the previous sections is based on a large corpus study focused on vowels with secondary stress. Therefore, the main aim of this paper is to evaluate how efficient the different generalisations are in a large corpus. In doing so, I will seek to determine which of Fournier's or Guierre's analyses should be preferred or whether a new one should be proposed.

I will focus on the structures that correspond to the rules which are inferior to the rule $u$

$\rightarrow \overline{\mathrm{V}}$, i.e. vowels with secondary stress which are

monographs

not $<\mathrm{u}>$

followed by a single consonant, except in the case of transparent prefixes, for which cases with a following C2 will be preserved because such words will constitute relevant cases to establish the phonological autonomy of prefixes.

Vowels with these properties should be free from the influence of orthography and will be relevant to test the role of rank and of the right-hand context.

\section{Methodology}

The main ${ }^{13}$ data used for this study is a subset of the dataset used in Dabouis (2016), which contains 5829 words with a secondary stress. The pronunciations are taken from Wells (2008). Only the British pronunciation is considered. For full details on the constitution of this dataset and the choices that have motivated its structure, the reader is advised to see Dabouis (2016: \$6). For the purposes of this paper, let us simply say that certain categories that were problematic were left aside: proper names, compounds and words containing neoclassical roots. The online Oxford English Dictionary (henceforth OED) was used to check contemporaneity and "Britishness": all the words which were marked as rare, obsolete, as belonging to another variety of English or which had no entry were excluded.

Three categories of words have been extracted from this larger dataset, corresponding to the categories discussed in the previous sections:

Words with no morphological structure or formed with bound roots ( "non-derived words"; n=373).

Words containing a semantically transparent prefix $(n=388)$. This category includes both compositional constructions with a free base (e.g. co-driver, de-ice, pre-flight, redecorate) and non-compositional constructions or constructions with a bound base and for which the meaning of the prefix appeared to be potentially transparent at least for some speakers (e.g. decrease, export, premature, recycle, 
reflate). This last category is voluntarily broad so as to be able to capture all the cases for which the prefix is clearly not opaque and may be made prominent phonologically. However, this means that it is not a completely homogeneous category.

Stress-shifted suffixal derivatives ( $\mathrm{n}=1292)$. A word was treated as derived if a semantically related base existed in the OED, except if that base is marked as rare, obsolete or as belonging to another variety of English. The existence of a semantic relationship was established using the definitions in the OED. Rare cases for which a formal and historical relationship exists but the semantic relationship has been lost (e.g. appellation, hospitality, macaronic) have been left aside.

The results are discussed and interpreted in the following sections. Note that some of the words in the dataset may have several possible pronunciations. The only pronunciations considered here are those in which the relevant vowel has secondary stress. For example, harem can be pronounced ['ha:rəm], ['heərəm] or [(')ha:'rem]. The first vowel has secondary stress only in the third pronunciation and, therefore, only the realisation [a: ] is taken into consideration. The pronunciation [eə] only appears with primary stress and is not relevant here.

Finally, many of the words treated in the following sections are "foreign words". Such words cannot a priori be expected to abide by internal systemic rules, and this is indeed the case for primary stress placement. However, Dabouis (2016) has conducted a systematic investigation of "foreign" vocabulary and found no significant difference with "non-foreign" vocabulary both for stress placement and vowel values. This why no differences will be made between different types of vocabulary in this paper, although the foreignness of some of these words will be addressed when their behaviour diverges from that of "non-foreign" words (see \$4.1.3).

\section{Results and interpretation}

\subsection{Non-derived words}

Non-derived words will be analysed in three steps. First, I will discuss a configuration which has not been discussed in the literature and occurs marginally in the dataset: words stressed /21(-)/ (\$4.1.1). Indeed, this stress pattern should normally not occur because of the restriction against stress clashes. I will then analyse words which might obey the CiV rule (\$4.1.2) before turning to words which have more than one pretonic syllable (§4.1.3). Finally, I will propose an interpretation of these results in §4.1.4.

\subsubsection{The initial pretonic position $(n=38)$}

Although there are few words with that structure, their behaviour is relatively uniform: most of them have a $\overline{\mathrm{V}}$, as shown in Table 4 . 


\begin{tabular}{|c|c|c|}
\hline$\overline{\mathrm{V}}$ (including $\overline{\mathrm{V}}^{\mathrm{e}}$ ) & $\overline{\mathrm{V}}$ & $\overline{\mathrm{V}} \sim \overline{\mathrm{V}}$ \\
\hline $\mathbf{3 5} \mathbf{( 9 2 \% )}$ & $\mathbf{2} \mathbf{( 5 \% )}$ & $\mathbf{1} \mathbf{( 3 \% )}$ \\
amour, & menage \\
betise, bravo, cave, covert, debar, debouch, decant, \\
$\begin{array}{c}\text { decussate (adj), decussate (vb), demarche, dementia, } \\
\text { detour, dilute, direct, divan, divers, donee, elite, harem, } \\
\text { hotel, idea, kotow, lichee, migrate, milieu, motif, nonet, } \\
\text { petanque, prolix, retail, scalene, tirade, tycoon, typhoon }\end{array}$ & & \\
& & \\
\hline
\end{tabular}

Table 4. Vowel values in the initial pretonic position

Two words in the corpus display alternations which suggest that there is indeed something special with the initial pretonic position, as shown in (6).

(6) decussate (vb) [,di: 'kıseIt] ['dekəseit]

pineal ['pIn i_əl] [(,)paI'ni:əəl] ${ }^{14}$

These words have a $\bar{V}$ when the first vowel is in the initial pretonic position and a $\breve{V}$ when they have antepenultimate primary stress (as predicted by Luick's rule). This suggests that the difference in vowel values can be attributed to the difference in stress patterns. ${ }^{15}$

These results show that there is a rule applying in this environment. Let us call this rule, the « Rule of the Initial Pretonic ». It can be formulated as (7).

(7) $\mathrm{V} \rightarrow \overline{\mathrm{V}} / \# \mathrm{C}_{0--} \mathrm{CV}$ acc

\subsubsection{The CiV rule $(n=20)$}

The CiV rule applies very efficiently to primary stressed vowels in thousands of words (e.g. creátion, média, negótiate). ${ }^{16}$ However, as detailed below, this does not extend to vowels with secondary stress.

4 Let us first evaluate Fournier's (1994) proposal that this rule applies to words with the structure (-) $\dot{\sigma}\{i, e\} \mathrm{VC}_{0} \#$, i.e. for which the hiatus is made of the last two vowels of the word. There are very few words with that structure and some of them have been left aside because they could be related to words in which the vowel carries primary stress and that, as a consequence, the value could be preserved from these other words, as in (8).

(8) comèdiénne $\leftarrow$ ? Comedian

matèriél $\leftarrow$ ? material

Although the words on the right in (8) are not exactly bases in the traditional sense, it seems that, due to their high semantic and phonological relatedness, we cannot exclude the possibility that this relatedness will influence the pronunciation of words on the left in (8).

6 Once these two words have been left aside, we are left with two words, which do not behave uniformly: procreate has a $\overline{\mathrm{V}}$ while cabriole has a $\breve{V}$. As a consequence, there is not enough data to confirm or disconfirm Fournier's proposal.

When we extend our analysis to words which have the structure $(-))_{\sigma}\{i, e\} \mathrm{VC}_{0}(-)$, i.e. for which the vowel with secondary stress is followed by the hiatus, regardless of the position of the end of the word, there is no evidence of a rule or even a trend towards $\overline{\mathrm{V}} \mathrm{s}$, as shown by the results in Table 5 . 


\begin{tabular}{|c|c|c|}
\hline$\overline{\mathrm{V}}$ & $\overline{\mathrm{V}}$ & $\overline{\mathrm{V}} \sim \overline{\mathrm{V}}$ \\
\hline $\begin{array}{l}\mathbf{2}(\mathbf{1 0} \%) \\
\text { aviation, } \\
\text { procreate }\end{array}$ & $\begin{array}{c}\mathbf{1 5}(\mathbf{7 5 \%}) \\
\text { arietta, cabriole, cabriolet; } \\
\text { carioca, caryatid, coriander, } \\
\text { gladiolus, hacienda, kwashiorkor, } \\
\text { lavaliere, mariachi, ratiocinate, } \\
\text { ravioli, seriema, tapioca }\end{array}$ & $\begin{array}{c}\mathbf{3}(\mathbf{1 5 \%} \%) \\
\text { aleatoric, } \\
\text { olearia, } \\
\text { retiarius }\end{array}$ \\
\hline
\end{tabular}

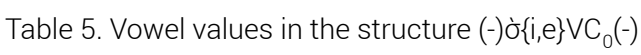

\begin{tabular}{|c|c|c|c|c|c|}
\hline & $/ 201(-) /$ & $/ 200(-) /$ & $/ 0201(-) /$ & $/ 0200(-) /$ & Total \\
\hline$\overline{\mathrm{V}}$ & 266 & 21 & 8 & & 295 \\
\hline$\overline{\mathrm{V}} \sim \overline{\mathrm{V}}$ & 13 & 1 & & & 14 \\
\hline$\overline{\mathrm{V}} \sim \overline{\mathrm{V}}$ & 6 & & & & 6 \\
\hline$\overline{\mathrm{V}}$ & 16 & 2 & 1 & 1 & 20 \\
\hline $\begin{array}{c}\text { Efficiency of } \\
\text { Luick's rule } \\
\text { (main pron. only) }\end{array}$ & $93 \%$ & $92 \%$ & $89 \%$ & $0 \%$ & $92 \%$ \\
\hline Examples & $\begin{array}{c}\text { còriánder } \\
\text { ànimósity } \\
\text { rèconcile }\end{array}$ & $\begin{array}{c}\text { àbracadábra } \\
\text { càricatúre } \\
\text { égalitárian }\end{array}$ & $\begin{array}{c}\text { apèritíf } \\
\text { amànuénsis } \\
\text { repètitéur }\end{array}$ & taràmasaláta & \\
\hline
\end{tabular}

Table 6. Vowel values for words having more than one pretonic syllable per stress pattern efficiency of Luick's rule was calculated by counting only the words which have a V their main pronunciation (the first two lines in Table 6). This yields an efficiency of $92 \%$ overall. If we count as "regular" all the words which can be pronounced with a Vi: (the first three lines in Table 6), that figure goes up to $94 \%$. The only word stressed /0200(-)/, taramasalata, has a $\overline{\mathrm{V}}^{\mathrm{e}}$. However, it would be far-fetched to make any conclusions on that stress configuration based on a single word, especially considering that some might want not to consider it as morphologically simple. ${ }^{18}$

Overall, the results favour Fournier's analysis rather than Guierre's. First, Luick's rule does seem to apply in words stressed /201(-)/. If the pretonic sequence were to behave in a similar fashion as the end of the word, we would not expect Luick's rule to apply here but the rules that apply to disyllables. Second, the rule of the penultimate does appear to apply in words stressed /0201(-)/: although there are few words with that stress pattern, most of them have a 
(9) a. $23 \overline{\mathrm{V}}^{\mathrm{e}}$ : bahuvrihi, bechamel, chiaroscuro, guacamole, maharaja, taràmasaláta...

b. 9 words with $<0>$ realised as [əठ]: coterie, olearia, oloroso, omerta, origami, provolone, pococurante, potoroo, rodomontade

c. 8 other exceptions: aleatoric, aviation, deleterious, ègalitárian, ipomoea, procreate, proletariat, retiarius

First, 23 words have a $\overline{\mathrm{V}}^{\mathrm{e}}$ (9a), which means that more than half of the exceptions could be attributed to the foreign character of these words. Second, nine words have $<0>$ realised as [əठ], which could be analysed as a $\overline{\mathrm{V}}^{\mathrm{e}}(9 \mathrm{~b})$. The reason for doing so is the foreignness of these words, which can be identified through etymology and through structural characteristics: penultimate or final stress, the endings <-ie, -a, -o, -i, (non-mute) -e, -oo, ade>, foreign vowels for the vowel with primary stress in coterie, omerta, origami and rodomontade. Remember that $<0>$ has no distinct foreign pronunciation, unlike $<\mathrm{a}, \mathrm{i}, \mathrm{e}>$. Considering that more than half of the exceptions are clearly identifiable foreign vowels, then it seems reasonable to assume that the exceptional pronunciation of words with $\langle 0\rangle$ in (9b) is in fact a $\bar{V}^{e}$. Finally, there are eight remaining exceptions which I cannot account for (9c). ${ }^{19}$ To conclude, it turns out that three quarters of the exceptions can be attributed to their foreign character.

\subsubsection{Interpretation}

First, let us sum up the results. It has been shown that vowels in the initial pretonic position generally have a $\bar{V}$. I have analysed this as a new rule: the Rule of the Initial Pretonic. This rule cannot be argued to be specific to vowels with secondary stress. Indeed, the primary stressed vowel of words stressed /12(-)/ would have to be studied. If one excludes compounds or transparent prefixed constructions, it might be that relevant cases will be very hard to find. We have also seen that there is no evidence for the CiV rule for vowels with secondary stress. Finally, in words with more than one pretonic syllable, we have seen that the vast majority of words seems to obey Luick's rule and therefore have V̆s. Most of the exceptions to Luick's rule have been shown to be foreign words. Overall, the evidence contradicts Guierre's proposal that the pretonic sequence behaves like the end of the word.

Fournier's analysis makes better predictions for most configurations but is faced with a problem when it comes to the new Rule of the Initial Pretonic. Indeed, some words, such as those in (10), have a stressed initial pretonic vowel which is also at least antepenultimate.

(10) decussate (adj), decussate (vb), dementia, idea ${ }^{20}$

If there was no Rule of the Initial Pretonic we would expect these words to have $\breve{V} s$ according to Luick's rule. None of them does. Let us go through three possible reasons why.

First, we can assume that this rule simply dominates Luick's rule, as suggested in Dabouis (2016). In the hierarchy presented in $\$ 1.2$, it would be the first referring to rank, meaning it would immediately precede Luick's rule.

Second, as suggested by Fournier (personal communication), the fact that the initial vowel is followed by a stressed syllable means that the single consonant that follows it unambiguously belongs to the second syllable, as opposed to most V́CV configurations, in which it is difficult to decide which syllable the medial consonant should belong to. If this 
is true, then the first syllable is clearly an open syllable and should follow the $\mathrm{C}^{0}$ rule, which correctly predicts that the vowel should be $\mathrm{a} \overline{\mathrm{V}}$.

Third, it could be that the formulation of Luick's rule should be revised. Defending this proposal requires using a theoretical tool which is not usually used in the Guierrian approach: the foot. Feet are prosodic units that contain one or more syllables; they have been widely used by phonologists since the 1970s in Metrical Phonology (Hayes 1980; Liberman \& Prince 1977) and Prosodic Phonology (Nespor \& Vogel 1986; Selkirk 1980, 1981), where feet are part of a hierarchy of prosodic constituents (e.g. the syllable, the prosodic word, the intonational phrase, etc.). As pointed out by Scheer (2011: 303), "prosodic categories have ceased to engage phonologists theoretically: the prosodic word and its peers have become descriptive categories, much in the way syllabic vocabulary such as onset and coda is used when informally talking about languages". In English, feet have been used to tie together a number of phenomena: stress, vocalic patterns, expletive infixation (Davis \& Cho 2003; Hammond 1999: \$5.4.3; McCarthy 1982), flapping, the obligatory assimilation of $/ \mathrm{n} /$ to a following stop, the mutual assimilation of $/ \mathrm{k} /$ and $/ \mathrm{r} /$, the devoicing of $/ \mathrm{l} /$ after a voiceless consonant (Kiparsky 1979), the aspiration of voiceless stops, the distribution of $[\mathrm{h}]$ and of $[\mathrm{r}]$ in certain American dialects (BermúdezOtero 2012; Davis \& Cho 2003; Harris 2013) and word-internal schwa syncope (Hammond 1999: §5.4.4).

Most works on English assume that, in this language, feet are normally bimoraic trochees (see Bermúdez-Otero \& McMahon (2006) and Pater (2000)). This means that they should contain at least two morae, assuming that a short vowel has one mora, a long vowel has two morae and coda consonants have one mora. Trochaicity means that, if the foot is disyllabic, then its head should be the leftmost syllable. Stress patterns are usually seen as manifestations of foot structure. Foot-heads and stresses are in a one-to-one relationship: wherever there is a foot-head, there should be a stress and wherever there is a stress, there should be a foot-head. Most theories also assume that vowels are lexically present and that syllable structure and foot structure are projected from the segmental structure. After Hayes (1982), most works also assume that the final syllable of nouns, the last consonant of verbs and certain suffixes are extrametrical, i.e. they are invisible to the stress-assigning algorithm.

51 Within the framework of a reading grammar, which is what is usually studied in the Guierrian approach, one of these assumptions cannot be adopted. Indeed, in a reading grammar, vowel values need to be accounted for and therefore cannot be assumed to be lexical. Moreover, the rules given in $\$ 1.2$ are highly efficient if spelling is taken into consideration but less so if it is not. As a consequence, feet may not be derived from segmental structure, or at least may not be determined by vowel length. ${ }^{21}$ Here, I am going to assume that stress is assigned with the rules proposed by Fournier $(2007,2010)$, which do not require any reference to vowel length or fullness. Additionally, I am not going to assume that there exists a one-to-one relationship between feet and stress. I will assume that a stressed vowel is the head of a foot but not that the head of a foot is necessarily stressed. This is in line with proposals such as Gussenhoven (1991), who claims that there are two kinds of prominence in English: foot structure, which "captures the distinction between reduced and unreduced syllables", and what he calls "accent", which he defines as "a place marker in the phonological structure where tones are to be inserted" (Gussenhoven 2011). I will keep using the word "stress" to refer to the second kind of prominence. ${ }^{22}$ 
Once we have made these assumptions, it should be possible to derive vowel values through foot structure. Note that this proposal is exploratory and that many of the aspects of the analysis developed below are still to be refined. I am going to focus on words which normally obey the rules of vowel value that refer to rank. Let us take the two possible pronunciations of the word coronal and assume, in line with most works on English phonology, that the adjectival suffix -al is extrametrical. If stress is on the antepenultimate, the foot can be disyllabic and, to be bimoraic, requires the first syllable to be short (11a). If stress is on the penultimate, the foot cannot include the final syllable because it is extrametrical. As a consequence, the vowel has to be long to satisfy bimoraicity (11b). ${ }^{23}{ }^{24}$

(11)

\section{a. córonal}

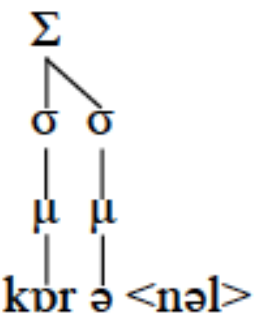

\section{b. corónal}

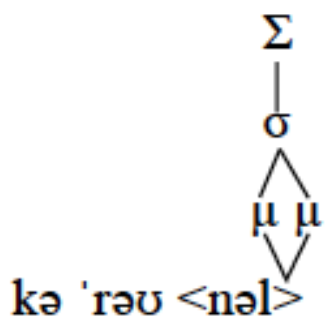

25

Assuming that the last syllable is extrametrical also means that Luick's rule in fact refers to a sequence of two syllables and not three syllables. In the generative literature, it has been reanalysed as "Trochaic Shortening" (Prince 1991). This analysis predicts that there will be a difference between vowels with secondary stress which are followed by an unstressed vowel and those followed by another stressed vowel. Those followed by an unstressed vowel should obey Luick's rule, because the foot can be disyllabic, as in (12).

(12)

\section{ànimósity}

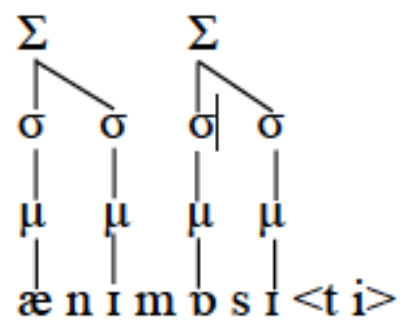

In the initial pretonic position, this analysis predicts the effects of the Rule of the Initial Pretonic: the vowel should be long because the foot can only be monosyllabic, just as in (13b). The two pronunciations of pineal can therefore be represented as in (13). 
a. píneal

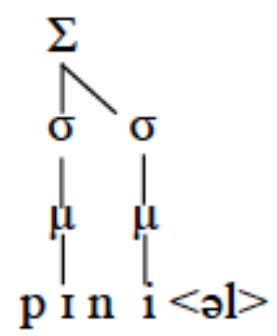

b. pìnéal

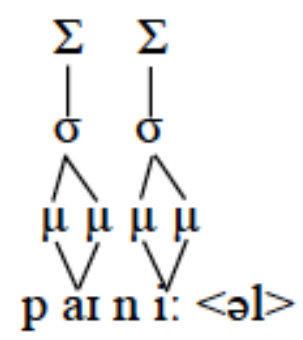

If we also adopt the assumption that, in verbs, only the last consonant is extrametrical, then we should expect Luick's rule to apply to verbs with penultimate stress. Indeed, the last syllable can be part of the foot and the stressed vowel should then be short, as in (14).

\section{a. gáther}

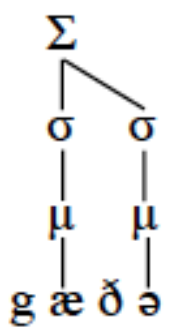

\section{b. devélop}

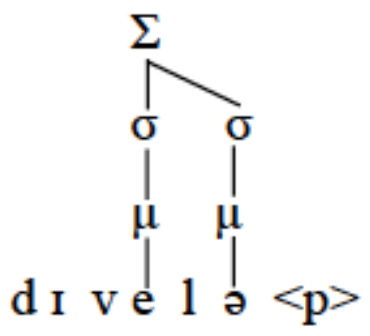

I tested this prediction on the dataset used in Dabouis \& Fournier (in preparation), which is a dataset of over 5000 verbs listed in Jones (2006). I extracted all the verbs which are not suffixed, do not contain a transparent prefix, are not compounds and which have the proper environment for Luick's rule (i.e. a monograph stressed vowel that is not $<\mathrm{u}>$ and is followed by a single consonant). The results are shown in Table 7.

\begin{tabular}{|l|l|l|}
\hline & $\breve{V}$ & $\bar{V}$ \\
\hline Disyllables & $\begin{array}{l}\text { blather, bury, bother, copy, cover, covet, cozen, dither, drivel, } \\
\text { fathom, foray, gather, govern, grovel, harass, herald, hover, kibitz, } \\
\text { quiver, ravel, raven, scavenge, shiver, shrivel, slaver, slither, } \\
\text { smother, snivel, smother, travail, travel, wither, wizen }\end{array}$ & $\begin{array}{l}\text { blazon, caper, } \\
\text { pater, open, } \\
\text { peter }\end{array}$ \\
\hline Trisyllables & $\begin{array}{l}\text { consider, continue, deliver, develop, dishevel, disparage, envelop, } \\
\text { examine, imagine, recover }\end{array}$ & $\begin{array}{l}\text { bedizen, } \\
\text { environ }\end{array}$ \\
\hline & $43(86 \%)$ & $7(14 \%)$ \\
\hline
\end{tabular}

Table 7. Vowel values in verbs with penultimate stress

57 These results confirm the predictions made by the analysis using feet and extrametricality. They are also interesting because the predictions made by this 
theoretical analysis have allowed the identification of a new generalisation: in the Guierrian tradition, it had never been observed that a specific rule applies to verbs. ${ }^{26}$

To sum up, all three analyses of the rules referring to rank can account for the data. However, although the third analysis is only a first approximation of how the rules of vowel value can be analysed using feet and extrametricality, it seems worth further research, as it has already allowed the unveiling of an empirical fact which had been missed by previous Guierrian works. Furthermore, if the entire system of rules for vowel values can be analysed using foot structure, it means that all the phenomena evoked above (e.g. flapping, aspiration, syncope) which have been attributed to foot structure could now be accounted for in a model which, at this stage, cannot account for them.

\subsection{Semantically transparent prefixes $(n=388)$}

\subsubsection{Results}

The vocalic behaviour in this inventory is extremely uniform: 380 words (99\%) can only be realised with a $\overline{\mathrm{V}}$ and six additional words may have it as a variant. The number of following consonants (or syllables) does not have any influence, as shown by the examples in (15).

(15) C: asexual, co-pilot, decipher, precook, redeploy...

$\mathrm{C}_{2}$ : astable, deskill, pre(-)flight, prestressed, reschedule...

Prefixed constructions with bound bases such as those in (16) overall have the same behaviour as those with free bases.

(16) cohabit, deflate, desalinate, decelerate, premonitory, regenerate, regress...

61 There is one exception with a bound base in which the prefix is followed by two consonants: agnostic [(,)æg'npsttk]. If we compare it to words which share the same base, diagnostic and prognostic, it seems difficult to argue that the $[\mathrm{g}]$ is actually part of the prefix because it is present in these words too, although their prefix is different. A possible explanation might be that the [gn] is ungrammatical domain-initially and that this forces the prefix to merge with the domain of its base, allowing the consonant cluster to influence the realisation of the vowel preceding it.

In analysing these data, it is important to identify which elements can be used to support the idea that prefixes can have their own phonological domain. Words for which the prefix is followed by $\mathrm{C}_{2}$ are fairly straightforward: leaving aside agnostic (which was discussed in the previous paragraph), all 26 words have a $\bar{V}$. This is clear evidence that the prefix has its own domain because, if it belonged to the same domain as the base, we would expect the rule $C_{2} \rightarrow \breve{V}$ to apply, which it does not.

However, the words for which the prefix-final vowel is followed by a single consonant and is in the initial pretonic position (e.g. àséxual, dèrail, rèfúnd) cannot be used as evidence for the phonological autonomy of prefixes because they could be obeying the Rule of Initial Pretonic found in \$4.1.1. If we consider the words for which the prefix-final vowel is followed by a single consonant and whose second syllable is unstressed (e.g. coprodúce, deseléct, prèdefine, rèdeploy), 69/74 words (93\%) can only be realised with a $\overline{\mathrm{V}}$, and $73 / 74$ (99\%) have $\bar{V}$ as a possible pronunciation. Note that there is only one exception out of 66 words with free bases: athematic, which will be discussed below. Among words with bound bases, the situation is rather unclear, as shown in (17).

(17) $\overline{\mathrm{V}}$ : predecessor, predilection, recapitulate, repercussion 
$\overline{\mathrm{V}} \sim \breve{\mathrm{V}}$ : premature, premonition, recrudesce

$\breve{V}$ : reviviscence

The reason for this is that the words with bound bases included in this dataset constitute a somewhat heterogeneous group. I have included in this group words for which the meaning of the prefix could be accessed at least by some speakers, based on the definitions given by the OED. This led to the inclusion of relatively unproblematic cases such as those listed in (16) but also to that of more problematic cases such as the ones in (17). Therefore, the V̆s observed in these words can be attributed to the fact that, to most speakers, the semantics of the prefixes are not transparent and that, as a consequence, they can undergo Luick's rule. To sum up, we can say that there is solid evidence for the phonological autonomy of prefixes in constructions with free bases but that the evidence is less conclusive in constructions with bound bases.

Let us conclude by noting the curious behaviour of the privative prefix $a^{-}$. As shown in (18), three words can have a $\breve{V}$, including two in the initial pretonic position, making them exceptions both to the Rule of the Initial Pretonic and to the general behaviour of transparent prefixes.

(18) $\overline{\mathrm{V}} \sim \breve{\mathrm{V}}$ : amoral, atonic

$\breve{\mathrm{V}} \sim \overline{\mathrm{V}}$ : athematic

$\overline{\mathrm{V}}$ : acyclic, asexual, atonal, atypical, avirulent, ahistorical, apolitical, aperiodic + astable (C2)

\subsubsection{Interpretation}

The high uniformity of the vocalic behaviour observed in this inventory makes the interpretation relatively easy. The large majority of significant cases point to the fact that prefixes behave like independent phonological units: Luick's rule the rule $C_{2} \rightarrow \breve{V}$ have no effect. Therefore, these results are consistent with an analysis in which this type of prefix has its own phonological domain, as discussed in \$1.3.2.

\subsection{Stress-shifted suffixal derivatives}

\subsubsection{Vowel preservation}

\subsubsection{One pretonic syllable $(n=12)$}

67 There are hardly any derivatives stressed /(2)1(-)/ and which are derived from a base with primary stress on its first syllable. This is hardly surprising considering that English normally prohibits stress clashes. In the twelve relevant words in the corpus listed in (19), only $\overline{\mathrm{V}} \mathrm{s}$ are attested.

(19) cocaine, demarcative, dinette, irate, limeade, migration, migratory, motet, nineteen, payee, pineal, piratical, poseur

These vowels can be accounted for by vowel preservation or by the Rule of the Initial Pretonic. As there is no way to tell which applies here, these words will not be treated as evidence for any of these rules and will not be discussed any further.

\subsubsection{Two pretonic syllables $(n=793)$}

In the vast majority of cases, the derivative has the same value as that of the vowel in the base, even if that vowel is unstressed in the base. Only the cases for which a full vowel can be found in the base (see the examples in (20)), as a main pronunciation or as a variant, 
were included in this analysis. The words for which the base has a reduced vowel are discussed in \$4.3.2.

(20) enigma [i'nIgmə e-, ə-] $\rightarrow$ enigmatic [,enIg'mætık]

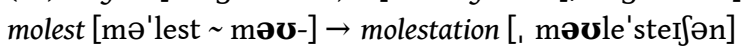

Cases for which the vowel is a $\overline{\mathrm{V}}$ or is alternating between a $\overline{\mathrm{V}}$ and a $\breve{\mathrm{V}}$ provide evidence that the pronunciation of the derivative depends on that of its base (see (21)).

(21) glóbalize $\rightarrow$ glòbalizátion $\overline{\mathrm{V}}$

negótiate $\rightarrow$ negòtiátion $\overline{\mathrm{V}}$

aménable $\rightarrow$ amènability $\overline{\mathrm{V}} \sim \breve{V}$

Indeed, if the pronunciation of the derivative were calculated independently of the base, we would expect Luick's rule to apply, regardless of the value of the vowel in the base. However, as shown in Table 7, the value found in the derivative is almost systematically identical to that found in the base.

\begin{tabular}{|c|c|c|c|c|c|c|}
\hline \multirow{2}{*}{$\begin{array}{r}\text { Value base } \\
\text { Value derivative }\end{array}$} & \multicolumn{3}{|c|}{$\overline{\mathrm{V}}$} & $\overline{\mathrm{V}}$ & \multicolumn{2}{|c|}{$\overline{\mathrm{V}}$ or $\overline{\mathrm{V}}$} \\
\hline & $\overline{\mathrm{V}}$ & $\begin{array}{ll}\overline{\mathrm{V}} & \text { or } \\
\overline{\mathrm{V}} & \end{array}$ & $\breve{\mathrm{V}}$ & $\overline{\mathrm{V}}$ & $\overline{\mathrm{V}}$ or $\overline{\mathrm{V}}$ & $\overline{\mathrm{V}}$ \\
\hline V stressed in the base & $\begin{array}{c}124 \\
(96 \%)\end{array}$ & $\begin{array}{c}3 \\
(2 \%)\end{array}$ & $\begin{array}{c}2 \\
(2 \%)\end{array}$ & $\begin{array}{c}479 \\
(100 \%)\end{array}$ & $\begin{array}{c}29 \\
(97 \%)\end{array}$ & $\begin{array}{c}1 \\
(3 \%)\end{array}$ \\
\hline $\mathrm{V}$ unstressed in the base & $\begin{array}{c}55 \\
(98 \%)\end{array}$ & $\begin{array}{c}1 \\
(2 \%)\end{array}$ & $\begin{array}{c}0 \\
(0 \%)\end{array}$ & $\begin{array}{c}95 \\
(100 \%)\end{array}$ & $\begin{array}{c}3 \\
(75 \%)\end{array}$ & $\begin{array}{c}1 \\
(25 \%)\end{array}$ \\
\hline
\end{tabular}

Table 7. Vowel preservation in suffixal derivatives

The exceptions are all listed in (22).

(22) a. $\bar{V} \rightarrow \bar{V}$ or V̆: íris $\rightarrow$ ìridáceous, sópor $\rightarrow$ sòporífic, ária $\rightarrow$ àrióso

$\overline{\mathrm{V}} \rightarrow \breve{V}$ : méthane $\rightarrow$ mèthanóic, Póland/Pólish $\rightarrow$ polonaise

$\overline{\mathrm{V}}$ (unstressed) $\rightarrow \overline{\mathrm{V}}$ or $\breve{V}:$ prorógue $\rightarrow$ prorogation

b. $\bar{V}$ or $\breve{V} \rightarrow \bar{V}$ : símony $\rightarrow$ sìmoníacal

$\overline{\mathrm{V}}$ or $\breve{V}$ (unstressed) $\rightarrow \overline{\mathrm{V}}$ : psoríasis $\rightarrow$ psòriátic

There are two striking observations about these exceptions. First, whenever the base has a $\breve{V}$,t hat value is also found in the derivative, without a single exception. Second, whenever a value that is absent from the base can be found in the derivative, it is always $\breve{V}$ (as in (22a)). These two observations confirm the idea that, in this environment, Luick's rule is the default, as was observed with non-derived words. It can be argued that the words of (22a) have a semantic relationship that is not completely transparent, which could explain that the derivatives would develop pronunciations that are independent from that of their base and which would abide by general structural rules. In the case of bases with a $\breve{V}$, such cases would be undetectable from their pronunciation because both vowel preservation and Luick's rule would predict the same pronunciation.

\subsubsection{Three or more pretonic syllables $(n=402)$}

Words with a longer pretonic sequence preserve the vowel value found in their base without a single exception, even when there is variation in the base. Examples are listed in (23).

(23) V̆: abòminátion, càtegorizátion, èducabílity, familiárity, rèlativístic...

$\overline{\mathrm{V}}$ : acètificátion, chamèleónic, degràdabílity, expèriéntial, globalizátion...

$\overline{\mathrm{V}} \sim \breve{V}$ : amènabílity, ephèmerálity, excòriátion, scàrificátion... 

been included in the previous counts. When the vowel is reduced, we would expect Luick's rule to apply, just as it does for non-derived words, because there is no retrievable source for the value of the vowel. However, this is not exactly what we find, as shown by the results in Table 8.

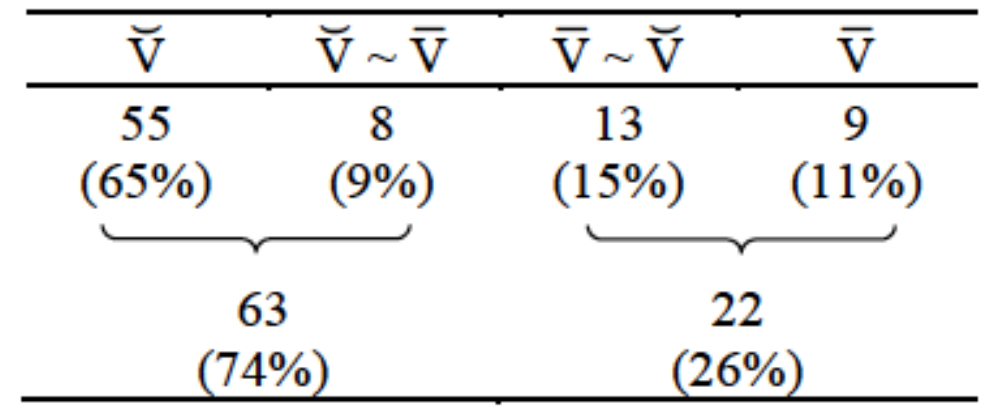

Table 8. Vowel values in stress-shifted derivatives whose base has a reduced vowel

79 If we evaluate the efficiency of Luick's rule in these words in the same way as it was evaluated for non-derived words in \$4.1.3, i.e. measuring the proportion of words which have a $\breve{V}$ as their main pronunciation, we can observe that this proportion is about $20 \%$ lower than that found in non-derived words (74\% vs $92 \%)$. Indeed $35 \%$ of words here can have a $\bar{V}$, as in the examples in (26).

(26) $\overline{\mathrm{V}}: d[\mathrm{i}:]$ partméntal $\leftarrow$ department; $c[\mathrm{ì}:]$ mentátion $\leftarrow$ cemént

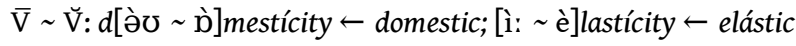

$\breve{\mathrm{V}} \sim \overline{\mathrm{V}}: d[\mathrm{è} \sim \grave{\mathrm{i}}:]$ molition $\leftarrow$ demólish $;$ pr[ $[\mathrm{\textrm {o }} \sim$ ว̀v $]$ ductívity $\leftarrow$ prodúctive

The issue is to explain this unexpected presence of $\bar{V} s$ in these words. A series of hypotheses can be made. First, the dataset contains a number of historically prefixed words, which have been shown to have an effect on phonology (Dabouis 2017a), so it may be that the $\bar{V}$ that we observe can be attributed to morphology. Second, it may have to do with the vowel found in the second syllable. Indeed, Videau (2013: §3.5) observes that the prefixes de- and re- may be realized with a $\overline{\mathrm{V}}$ when the second syllable is not reduced, even when they are semantically opaque. This is reminiscent of the so-called "Arab Rule", which applies to words showing vowel reduction in syllables closed by a non-coronal 
obstruent and preceded by a light syllable (e.g. Arab ['ærəb]) but not when the preceding syllable is heavy (e.g. Arab ['eIræb]) (Collie 2007; Hayes 1980; Pater 1995, 2000; Ross 1972). The directionality of the relationship between the two syllables is unclear so, if a relationship between the absence of reduction and the value of the first vowel were to be found, we would have to determine whether the absence of reduction is causing the preceding vowel to be free or if it is the presence of a free vowel in the first syllable that prevents vowel reduction in the second syllable. Finally, the last hypothesis has to do with the reduced vowel that is found in the base. In the data, considering the main variant only and excluding $<\mathrm{i}>$ realised as [I] (which could be either a full or a reduced vowel), only two reduced vowels are found: [i] and [ə]. We could expect words whose base has [i] to be more likely to have a $\bar{V}$ than those whose base has [ə] because, in Wells (2008), [i] is actually a representation of the neutralization of the [i: ] [I] contrast. The free vowel in that pair of vowels is the normal realization of <e>, which is how [i] is spelled in this dataset. Therefore, one could assume that having [i:] in the derivative is a form of vowel preservation (as opposed to a direct computation of the vowel).

These three potential factors (morphology, vowel reduction in the second syllable ${ }^{27}$ and the reduced vowel in the base) were tested together in a binary logistic regression with the vowel value of the derivative as the dependent variable, coded as a binary variable: $\overline{\mathrm{V}}$ possible or $\breve{V}$ only. The results of this analysis are shown in Table 9.

\begin{tabular}{|l|l|l|l|l|}
\hline & \multicolumn{2}{|l|}{$95 \%$ CI } & \multirow{2}{*}{ p-value } \\
\hline & Inf & OR & Sup & \\
\hline VRED-i & 1,27 & 4,22 & 16,15 & 0,0237 \\
\hline V2-RED & 0,02 & 0,08 & 0,24 & 0,00002 \\
\hline
\end{tabular}

Table 9. Binary logistic regression for the value of the secondary stressed vowel in suffixal derivatives whose base has a reduced vowel

This analysis shows that there are two significant predictors: the vowel in the base (weakly) and the reduction of the second vowel in the derivative. The chances of having a $\bar{V}$ in the derivative are greater if the base has [i] and if the second vowel of the derivative is full. Because I have already proposed how to interpret the difference between [i] and $[ə]$ and that this parameter is only a weak predictor of the vowel value in the derivative, I will not discuss it any further and will focus on vowel reduction in the second syllable. As I mentioned above, we need to establish the directionality of the relationship between the value of the vowel of the first syllable and the (absence of) vowel reduction in the second syllable. In order to do so, it is necessary to establish what determines vowel reduction in this environment. This is the object of the next section. Then, in $\$ 4.3 .4$, I will propose a formal analysis of the results using the foot-based analysis developed in \$4.1.4.

\subsubsection{Parallel issue: vowel reduction in /201(-)/}

Before evaluating the parameters that determine vowel reduction, let us go through those that have been proposed in the literature. It has been claimed that: 
Vowels in open syllables are more likely to reduce than vowels in closed syllables (Burzio 1994: 113; Fudge 1984; Halle \& Keyser 1971).

Vowels in syllables closed by obstruents are less likely to reduce than vowels closed by sonorants (Pater 2000).

Vowels in syllables closed by non-coronals are less likely to reduce than vowels closed by coronals Burzio 1994; Dahak 2011; Fudge 1984).

Initial pretonic closed syllables normally do not reduce except if that syllable is a prefix Chomsky \& Halle 1968: 118; Collie 2007: 129, 215, 318; Guierre 1979: 253; Halle \& Keyser 1971; Halle \& Vergnaud 1987: 239; Hammond 2003; Hayes 1982; Liberman \& Prince 1977; Pater 2000; Selkirk 1980).

Vowels spelled with a digraph reduce less than monographs, especially in the initial pretonic position (Dahak 2011; Deschamps 1994: 111; Deschamps et al. 2004: 217; Guierre 1984, 1987).

Vowels in a syllable closed by a non-coronal obstruent and preceded by a heavy syllable should not reduce (e.g. Àl[ə]xánder vs. Tìmb[ $[\Lambda$ któo; see the discussion on the "Arab Rule" in the previous section).

More frequent words show more reduction than less frequent words (Fidelholtz 1975).

These parameters have been evaluated for non-derived words in a recent preliminary study on vowel reduction (Dabouis et al. 2018). The dataset used in this study contains 478 words taken from Wells (2008) which are stressed /201(-)/, are monomorphemic or derived from bound roots, do not contain a historical prefix in the second syllable and are not proper names (which were not included at this stage in the study). Words with $<\mathrm{i}>$ realised as [I] in the second syllable were left out. The following predictors where used in a binary logistic regression:

CLOSEDNESS: syllables are coded as OPEN or CLOSED.

NATUREOFFOLLOWINGC: the nature of the following consonant was coded

((non)coronal, nasal, etc.).

LOGFREQUENCY: token frequency taken from SUBTLEX-UK (Van Heuven et al. 2014),

which was log-transformed so as to resemble the way "humans process frequency

information" (Hay \& Baayen 2002).

SPELLING: vowels were coded as MONOGRAPH or DIGRAPH.

WEIGHTOFS1: The first syllable was coded as HEAVY or LIGHT.

The dependent variable, vowel reduction, was coded as a binary variable (REDUCED vs. FULL ), based on the main pronunciation given by Wells (2008). As mentioned above, this is a preliminary study and a possible refinement could be the inclusion of the pronunciation variants given by Wells so that vowel reduction could be coded as a four-point scale depending on the existence and ordering of variants, as in Hammond (2003). The results from the analysis are shown in Table 10.

\begin{tabular}{|l|l|l|l|l|}
\hline & \multicolumn{3}{|l|}{$95 \%$ C.I. } & \multirow{2}{*}{ p-value } \\
\hline & Lower & OR & Higher & \\
\hline SPELLING-MONOGRAPH & 3.1 & 12.8 & 28.6 & $1.55 \mathrm{e}-04$ \\
\hline CLOSEDNESS-OPEN & 5.8 & 12.3 & 44.2 & $2.38 \mathrm{e}-10$ \\
\hline LOGFREQUENCY & 1.1 & 1.3 & 1.7 & 0.011 \\
\hline
\end{tabular}

Table 10. Binary logistic regression for vowel reduction in the intertonic position in non-derived words 

stressed can reduce its chances to reduce (Chomsky \& Halle 1968: 112, e.g. reláx $\rightarrow$
rèlaxátion), even more so if that base is more frequent than the derivative (BermúdezOtero (2012: 32), after Krazka-Szlenk (2007: §8.1.2). Therefore, I conducted another study on a subset of the dataset used in Dabouis (2017b). This dataset contains derived words stressed /201(-)/ with a base stressed /01(-)/ which are taken from Wells (2008). For the purposes of this study, certain words had to be left out:

Words with $<\mathrm{i}>$ realised as [I] in the second syllable because it is impossible to know whether the vowel is full or reduced;

Words with a disyllabic prefix (e.g. inter-, super-), because the systematic reduction in their second syllable could be attributed to idiosyncratic properties of the prefix itself;

Words with a re-writing of the stressed vowel in the base (e.g. reveal $\rightarrow$ revelation), because having a diacritic mark of length in the base (i.e. the digraph) and not in the derivative could bias the results;

Words with a frequency of 0 and a base with a frequency superior to 0 , because a frequency ratio cannot be computed for these words.

The final dataset contains 200 words. The same variables as for non-derived words were used and some new ones were added:

LogFrequency-Base: the frequency of the base, again taken from SUBTLEX-UK and log-transformed. The name of the frequency variable for the derivative was changed to LogFrequency-Derivative.

RelativeFrequency: the ratio of the base frequency and the derivative frequency. SemanticTransparency: Semantic transparency was coded using Dictionary.com (http://dictionary.reference.com/, accessed 04/06/2018). The relationship between the base and its derivative was coded as Transparent if the base appeared in the definition of the derivative. Otherwise, the relationship was coded as Nontransparent.

These variables were tested in a binary logistic regression with vowel reduction (again coded as FULL or REDUCED) as the dependent variable. The results are shown in Table 11.

\begin{tabular}{|l|l|l|l|l|}
\hline \multicolumn{3}{|l|}{$95 \%$ C.I. } & \multirow{2}{*}{ p-value } \\
\hline & Lower & OR & Higher & \\
\hline CLOSEDNESS-OPEN & 8.4 & 17.8 & 40.9 & $8.31 \mathrm{e}-13$ \\
\hline SPELLING-MONO & 1.2 & 9.8 & 103.0 & 0.039730 \\
\hline LOGFREQUENCY-DERIVATIVE & 1.2 & 1.3 & 1.6 & 0.000101 \\
\hline
\end{tabular}

Table 11. Binary logistic regression for vowel reduction in the intertonic position in derived words

91 These results show that the exact same variables turn out to be significant predictors of vowel reduction in derived words as those found in non-derived words. Note, however, that the effect of spelling is only marginally significant. No effect can be associated to the 
weight of the first syllable, the nature of the following consonant or relative frequency, contrary to what has been claimed in the literature. Let us now compare non-derived words and derived words.

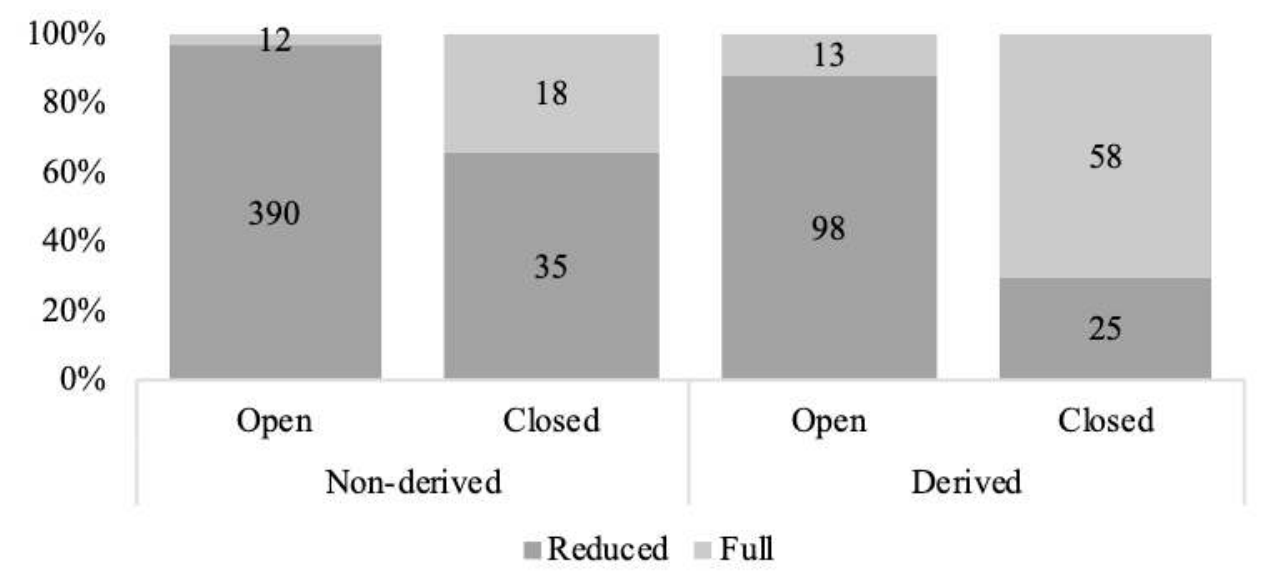

Figure 1. Vowel reduction in the intertonic position of non-derived and derived words

Figure 1 shows that, overall, vowels reduce less in derived words than in non-derived words. The pairwise comparison between open syllables in non-derived and derived words $\left(\chi^{2}=12.469,1 \mathrm{df}, \mathrm{p}<0.001\right)$ and between closed syllables in non-derived and derived words ( $\left.\chi^{2}=15.5,1 \mathrm{df}, \mathrm{p}<0.0001\right)$ confirms that this observation is significant. This suggests that, although no effect of relative frequency or semantic transparency could be found, the mere existence of a base reduces the chances of vowel reduction in this position. A complementary element goes in the same direction: $8 / 25$ derivatives in which the second vowel is not reduced can also be stressed /021(-)/. This highly exceptional stress pattern can very clearly be attributed to isomorphism with the base (see Dabouis 2017b), which suggests that the lower rate of vowel reduction can be too.

Significantly, the first syllable does not appear to affect the reduction of the second vowel. These results suggest that in words such as $c[i \mathrm{i}]$ mentation, the $\overline{\mathrm{V}}$ observed in the first syllable can be attributed to the non-reduction of the second vowel, and not the opposite.

\subsubsection{Interpretation}

First, we have seen that vowel preservation is the main force determining vowel values in derived words. A new finding is the fact that this vowel preservation operates even when the first syllable is unstressed in the base and that it bears secondary stress in the derivative (e.g. molest [mə'lest məठ-] $\rightarrow$ molestation [, məəle'steIfən]. Fournier's (1994) analysis supposes than if secondary stress shifts to the first syllable to avoid a stress clash, then the value of the first vowel should be computed directly, even if it is full in the base. The results reported here clearly show that this is incorrect: whenever a full vowel exists in the base, its value is preserved in the derivative.

The results have also shown that, whenever a vowel value which cannot be attributed to vowel preservation is found in the derivative (when it contains a full vowel), it is always a , confirming the hypothesis that this is the default value in this environment. 
97 Finally, we have seen that derivatives whose base has a reduced vowel generally obey Luick's rule, although much less efficiently than would be expected if they behaved like non-derived words. Indeed, $35 \%$ of these derivatives can have a $\bar{V}$. It was shown that this value can be attributed to the absence of vowel reduction in the second syllable and (marginally) to the reduced vowel found in the base. The study of vowel reduction in the intertonic position has shown that vowel reduction was not conditioned by properties of the first syllable, suggesting that it is indeed the absence of reduction that leads to $\bar{V} s$ in the first syllable and not the opposite. Interestingly, the results on vowel reduction have shown that vowels were less likely to reduce in derived words than in non-derived words. Therefore, to some extent, the presence of $\bar{V}$ s in stress-shifted derivatives can indirectly be attributed to isomorphism with the base. This observation once again shows how strong isomorphism is in English.

Once again, using feet as a theoretical tool to represent the distinction between reduced and full vowels can prove useful to analyse the data I have just described. First, let us assume that the conjunction of syllable structure and identity with the base forces the preservation of the foot that bears primary stress in the base, as in (27).

(27)

\section{cemént}

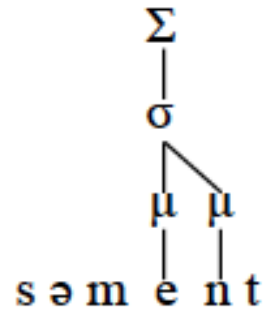

\section{cementátion}

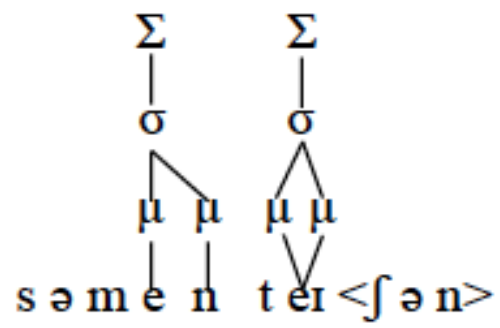

As stress cannot be preserved on the second syllable because of the prohibition of stress clashes, secondary stress must be placed on the first syllable. As the second syllable already belongs to a foot, the first syllable will have to form a foot of its own. Finally, because this syllable is open and that a foot must be at least bimoraic, then the first vowel will have to be long, as shown in (28). ${ }^{28}$

(28)

\section{cementátion}

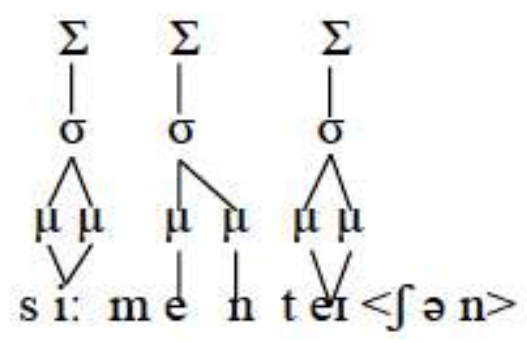




\section{Conclusion}

100

This paper has provided an extensive empirical study of the pronunciation of vowels with secondary stress. Most of the results confirm previous analyses but some newly unveiled phenomena require a revision of these analyses.

Non-derived words have been found to obey two rules: the (new) Rule of the Initial Pretonic when they have one pretonic syllable and Luick's rule in all other contexts. There was no evidence to support analyses claiming that the CiV rules also applies to vowels with secondary stress. Several possible analyses have been proposed to accommodate the Rule of the Initial Pretonic. One of them is an exploratory analysis using feet which, if it could be extended to the whole system of spelling-to-sound rules, would considerably broaden the empirical coverage of the theory because a number of phenomena which have been related to foot structure could now be integrated in the model. In this analysis, Luick's rule was revised so as to refer to the presence of a following (non-extrametrical) syllable rather than to rank.

The vowels found in vowel-final semantically transparent prefixes seem to support the claim that they have their own phonological domain. Under this assumption, they can be analysed as obeying the $\mathrm{C}^{0} \rightarrow \overline{\mathrm{V}}$ rule, regardless of their right-hand context.

Finally, it has been shown that suffixal derivatives almost systematically preserve the vowel value of the vowel found in the base, provided that this vowel is not reduced in the base. The observation that this preservation can operate even when the vowel is unstressed in the base contradicts Fournier's claim (1994) that structural rules should apply in these conditions. I have also shown that whenever a value that is absent from the base can be found in the derivative, it is always $\breve{V}$. This was taken as evidence confirming that the default pattern in words with more than one pretonic syllable is to have a $\breve{V}$, as predicted by Luick's rule. Derivatives stressed /201(-)/ with a base stressed /01(-)/ whose first syllable is reduced have been shown to have a greater proportion of $\overline{\mathrm{V}} \mathrm{s}$, contrary to what Luick's rule predicts. These $\overline{\mathrm{V}}$ s have been mainly attributed to the absence of vowel reduction in the second syllable. I have shown that an analysis using feet could be used to account for the interaction between the two syllables.

\section{BIBLIOGRAPHY}

Ben Hedia, S. \& Plag, I. (2017). Gemination and degemination in English prefixation: Phonetic evidence for morphological organization. Journal of Phonetics, 62, 34-49.

Bermúdez-Otero, R. (2012). The Architecture of Grammar and the Division of Labour in Exponence. In J. Trommer (Ed.), The Morphology and Phonology of Exponence (pp. 8-83). Oxford: Oxford University Press. 
Bermúdez-Otero, R. \& McMahon, A. (2006). English Phonology and Morphology. In J. Trommer (Ed.), The Handbook of English Linguistics (pp. 382-410). Oxford: Oxford University Press.

Booij, G. \& Rubach, J. (1984). Morphological and Prosodic domains in Lexical Phonology. Phonology Yearbook, 1, 1-27.

Burzio, L. (1994). Principles of English Stress. New York: Cambridge University Press.

Carr, P. (2000). Vowel Length in Standard Scottish English. In 10ème Colloque d'Avril sur l'anglais oral (pp. 13-24). Villetaneuse: Université de Paris-Nord, CELDA, diffusion APLV.

Chomsky, N. \& Halle, M. (1968). The Sound Pattern of English. Cambridge, MA, London, England: MIT Press.

Collie, S. (2007). English Stress Preservation and Stratal Optimality Theory. Ph.D. dissertation. University of Edinburgh.

Cruttenden, A. (2014). Gimson's Pronunciation of English (8th editio). Oxon \& New York: Routledge.

Dabouis, Q. (in preparation). English Phonology and the Literate Speaker: Some Implications for Lexical Stress. In N. Ballier, J.-M. Fournier, A. Przewozny, \& E. Yamada (Eds.), English Word Stress: Theories, Data and Variation. Oxford: Oxford University Press.

Dabouis, Q. (2016). L'accent secondaire en anglais britannique contemporain. Ph.D. dissertation. University of Tours.

Dabouis, Q. (2017a). Semantically Opaque Prefixes and English Phonology. 14th old World Conference in Phonology, (20-22th February, Düsseldorf).

Dabouis, Q. (2017b). When Accent Preservation Leads to Clash. English Language and Linguistics, $1-42$.

Dabouis, Q. Enguehard, G. Fournier, J.-M. \& Lampitelli, N. (2018). The English "Arab rule" without metrics. Paper Presented at the 26th MFM Conference at the University of Manchester.

Dabouis, Q. \& Fournier, J.-M. (in preparation). The stress pattern of English verbs: Syllable weight or morphology? In N. Ballier, J.-M. Fournier, A. Przewozny, \& E. Yamada (Eds.), English Word Stress: Theories, Data and Variation. Oxford: Oxford University Press.

Dahak, A. (2011). Etude diachronique, phonologique et morphologique des syllabes inaccentuées en anglais contemporain. Ph.D. dissertation. Université de Paris Diderot.

Davis, S. \& Cho, M.-H. (2003). The distribution of aspirated stops and /h/ in American English and Korean: an alignment approach with typological implications. Linguistics, 41(4), 607-652.

Deschamps, A. (1994). De l'écrit à l'oral et de l'oral à l'écrit. Paris: Ophrys.

Deschamps, A. Duchet, J.-L. Fournier, J.-M. \& O’Neil, M. (2004). English Phonology and Graphophonemics. Paris: Ophrys.

Duchet, J.-L. (2018). Code de l'anglais oral (new edition). Paris: Ophrys.

Fidelholtz, J. (1975). Word Frequency and Vowel Reduction in English. Chicago Linguistic Society, $11,200-213$.

Fournier, J.-M. (1994). La prononciation de la voyelle accentuée /2/en anglais RP. In 7ème Colloque d'Avril sur l'anglais oral (pp. 151-169). Villetaneuse: Université de Paris-Nord, CELDA, diffusion APLV. 
Fournier, J.-M. (1996). La reconnaissance morphologique. In 8ème Colloque d'Avril sur l'anglais oral (pp. 45-75). Villetaneuse: Université de Paris-Nord, CELDA, diffusion APLV.

Fournier, J.-M. (1997). (I) Synthèse - Dossier en vue de l'habilitation à diriger les recherches. Université de Paris 7.

Fournier, J.-M. (1998). Que contraignent les terminaisons contraignantes? In Topiques, Nouvelles recherches en linguistique anglaise, Travaux XCIII du CIEREC. Université de Saint-Etienne.

Fournier, J.-M. (2007). From a Latin syllable-driven stress system to a Romance versus Germanic morphology-driven dynamics: in honour of Lionel Guierre. Language Sciences, 29, 218-236.

Fournier, J.-M. (2010). Manuel d'anglais oral. Paris: Ophrys.

Fox, A. (2000). Prosodic Features and Prosodic Structure. New York: Oxford University Press.

Fudge, E. (1984). English Word Stress. London: G. Allen \& Unwin.

Guierre, L. (1979). Essai sur l'accentuation en anglais contemporain : Eléments pour une synthèse. Ph.D. dissertation. Université Paris-VII.

Guierre, L. (1984). Drills in English Stress Patterns: Ear and Speech Training Drills and Tests for Students of English as a Foreign Language (4th ed). Londres: A. Colin - Longman.

Guierre, L. (1987). Règles et exercices de prononciation anglaise (Paris). Longman France.

Gussenhoven, C. (1991). The English Rhythm Rule as an accent deletion rule. Phonology, 8, 1-35.

Gussenhoven, C. (2011). Sentential Prominence in English. In M. Van Oostendorp, C. J. Ewen, E. Hume, \& K. Rice (Eds.), The Blackwell Companion to Phonology (vol. 2: Suprasegmental and Prosodic Phonology)2 (pp. 2778-2806). Malden, MA: Wiley-Blackwell.

Halle, M. \& Keyser, S. (1971). English Stress: Its Form, Its Growth, and its Role in Verse. New York: Harper \& Row.

Halle, M. \& Vergnaud, J.-R. (1987). An Essay on Stress. Cambridge, MA: MIT.

Hammond, M. (1999). The Phonology of English: A Prosodic Optimality-Theoretic Approach. (J. Durand, Ed.). Oxford: Oxford University Press.

Hammond, M. (2003). Frequency, cyclicity, and optimality. University of Arizona. URL: http:// www.u.arizona.edu/ hammond/kslides.pdf

Harris, J. (2013). Wide-domain r -effects in English. Journal of Linguistics, 49(2), 329-365.

Hay, J. \& Baayen, H. (2002). Parsing and Productivity. In G.E. Booij \& J. van Marle (Ed.), Yearbook of Morphology 2001 (pp. 203-235). Dordrecht: Kluwer.

Hayes, B. (1980). A Metrical Theory of Stress Rules. Ph.D. dissertation. MIT.

Hayes, B. (1982). Extrametricality and English Stress. Linguistic Inquiry, 13(2), 227-276.

Jensen, J. T. (2000). Against ambisyllabicity. Phonology, 17(2), 187-235.

Jones, D. (2006). Cambridge English Pronouncing Dictionary (17th ed). Cambridge: Cambridge University Press.

Kaye, A. S. (2005). Gemination in English. English Today, 21(2), 43-55.

Kiparsky, P. (1979). Metrical Structure Assignment is Cyclic. Linguistic Inquiry, 10(3), 421-441.

Krazka-Szlenk, I. (2007). Analogy: the Relation Between Lexicon and Grammar. LINCOM Studies in Theoretical Linguistics. Munich: LINCOM Europa. 
Liberman, M. \& Prince, A. (1977). On Stress and Linguistic Rhythm. Linguistic Inquiry, 8(2), 249336.

Luick, K. (1898). Beiträge zur englischen Grammatik III. Die Quantitäts Veränderungen im Laufe der englischen Sprachentwicklung. Anglia, 20, 335-362.

McCarthy, J. J. (1982). Prosodic structure and expletive infixation. Linguistics Department Faculty Publication Series. University of Massachusetts, Amherst. Paper 63.

Nespor, M. \& Vogel, I. (1986). Prosodic Phonology. Foris: Dordrecht.

Oh, G. E. \& Redford, M. A. (2012). The production and phonetic representation of fake geminates in English. Journal of Phonetics, 40(1), 82-91.

Oxford English Dictionary (online)

Pater, J. (1995). On the Nonuniformity of Weight-to-Stress and Stress Preservation Effects in English. Manuscript. McGill University.

Pater, J. (2000). Non-uniformity in English Secondary Stress: the Role of Ranked and Lexically Specific Constraints. Phonology, 17, 237-274.

Prince, A. (1991). Quantitative consequences of rhythmic organization. Papers from the TwentySixth Regional Meeting of the Chicago Linguistics Society, Vol. 2: The Parasession on the Syllable in Phonetics and Phonology, 26(1991), 355-398.

Prince, A. \& Smolensky, P. (1993). Optimality Theory: Constraint Interaction in Generative Grammar. Rutgers University and University of Colorado.

Raffelsiefen, R. (1993). Relating words: A Model of Base Recognition. Part I. Linguistic Analysis, (23), 3-161.

Raffelsiefen, R. (1999). Diagnostics for Prosodic Words Revisited: The Case of Historically Prefixed Words in English. In T. A. Hall \& U. Kleinhenz (Eds.), Studies on the Phonological Word (Current Issues in Linguistic Theory 174) (pp. 133-201). Amsterdam: John Benjjamins Publishing.

Raffelsiefen, R. (2007). Morphological Word Structure in English and Swedish: the Evidence from Prosody. Fifth Mediterranean Morphology Meeting, 209-268.

Ross, J. R. (1972). A Reanalysis of English Word Stress (Part I). In M. K. Brame (Ed.), Contributions to Generative Phonology (pp. 229-323). Austin: University of Texas Press.

Schane, S. A. (2007). Understanding English Word Accentuation. Language Sciences, 29(2-3), 372384.

Scheer, T. (2011). A Guide to Morphosyntax-Phonology Interface Theories. How ExtraPhonological Information is Treated in Phonology since Trubetzkoy's Grenzsignale. Berlin: Mouton de Gruyter.

Selkirk, E. O. (1980). The Role of Prosodic Categories in English Word Stress. Linguistic Inquiry, 11 (3), 563-605.

Selkirk, E. O. (1981). On Prosodic Structure and its Relation to Syntactic Structure. In T. Fretheim (Ed.), Nordic Prosody II (pp. 111-140). Trondheim: TAPIR.

Szpyra, J. (1989). The Morphology-Phonology Interface: Cycles, Levels and Words. London \& New York: Routledge.

Tournier, J. (1993). Precis de lexicologie anglaise (3rd ed.). Paris: Nathan.

Trevian, I. (2003). Morphoaccentologie et processus d'affixation de l'anglais. Bern: Peter Lang. 
van der Hulst, H. (2012). Deconstructing Stress. Lingua, 122(13), 1494-1521.

van der Hulst, H. (2014). Representing Rhythm. In H. Van der Hulst (Ed.), Word Stress:

Theoretical and typological issues. (pp. 325-365). Cambridge: Cambridge University Press.

Van Heuven, W. V. J. Mandera, P. Keuleers, E. \& Brysbaert, M. (2014). Subtlex-UK: A new and improved word frequency database for British English. Quarterly Journal of Experimental Psychology, (67), 1176-1190.

Videau, N. (2013). Préfixation et phonologie de l'anglais : Analyse lexicographique, phonétique et acoustique. Ph.D. dissertation. Université de Poitiers.

Wells, J. C. (2008). Longman Pronunciation Dictionary (3rd ed). London: Longman.

\section{NOTES}

1. Parts of this paper were presented at the 2018 ALAES/ALOES workshop of the SAES conference in Paris and at the Laboratoire Ligérien de Linguistique's seminar in Orléans. I am grateful to the audiences of these two venues for their questions and remarks. I would also like to thank JeanMichel Fournier and two anonymous reviewers for their constructive remarks and suggestions. Responsibility for any mistake or omission is mine alone.

2. Other foreign vowels include: French: $<\mathrm{ou}>\rightarrow$ [u:/və]: bijou, courgette; $<\mathrm{eu}>\rightarrow$ [3:]: danseur/ danseuse; <(e)au> $\rightarrow$ [əठ]: auberge, chateau; <oi, oy> $\rightarrow$ [wa: ]: boudoir; <é(e), ê, è> $\rightarrow$ [eI/eə]: negligée, déjà vu; "Classical": <ae, oe> $\rightarrow[i$ :]: Caesar, foetus; <aa > $\rightarrow$ [a:]: bazaar.

3. " $C$ " refers to any consonant, a subscript figure means "at least" and a superscript figure means "at the most". Therefore, C2 means "at least two consonants" (= two or more consonants) and C0 means "at the most zero consonants" (= no consonants). Following Fournier (2010: 28), C2 will here refer to $\langle\mathrm{x}>$ and to any cluster of at least two consonants, except for $\langle\mathrm{Ch}>,\langle\mathrm{Cr}\rangle,\langle\mathrm{Cre} \#>$ and

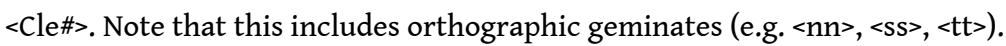

4. \# refers to a word boundary.

5. Fournier (2010: 141) represents the hierarchical organisation of rules using a form of decision tree.

6. There are also a few minor rules which have to do with disyllables only which are irrelevant here and therefore will not be discussed (but see Deschamps (1994: Ch. 10)).

7. The name "CiV Tensing" (or sometimes "CiV Lengthening") is often used in the generative literature and will be used here for convenience because of the complexity of the formulation of the rule.

8. After Luick (1898), who first described it. This rule is often called Trisyllabic Shortening or Laxing in the generative literature.

9. (-) refers to optional syllables.

10. In Prosodic Phonology, this domain is called the phonological (or prosodic) word (represented by $\omega$; see Booij \& Rubach, 1984; Raffelsiefen, 1993, 1999, 2007; Szpyra, 1989). Constructions with semantically transparent prefixes can be represented as (co) $\omega$ (habit) $\omega$, (pre) $\omega$ (cook) $\omega$ or (re) $\omega($ align $) \omega$.

11. Raffelsiefen (1993: 109-111) claims that two other phenomena indicate that prefixes can have their own domain. First, she claims that $[\mathrm{h}]$ can only appear in the intertonic position preceding a schwa if the first syllable is a prefix with its own phonological word: cp. re[Øə]bilitate ('restore to a former state') re[hə]bilitate ('habilitate again'). However, the facts are not as clear as she claims. As shown by Dabouis (2016: 511-513), the presence of [h] in the rare words with the relevant structure could be attributed to derivational identity with a base (e.g. in[hI I ə]bition $\leftarrow$ in[hí]bit) or to spelling pronunciations (as suggested by Raffelsiefen herself). 
Second, she claims that the absence of vowel reduction in the second syllable of words stressed /201(-)/ would indicate that an initial monosyllabic prefix has its own phonological word: cp. ref [ə]mation ('restoration') re-f[J:]mation ('action of forming again'). However, vowel reduction has not been the object of many empirical studies (but see Dabouis et al. 2018; Dahak 2011 and $\$ 4.3 .3$ below) and it seems premature to make this sort of claim before the roles of segmental structure, word frequency, derivational relationships and prosodic structure have clearly been established empirically.

12. Although it exceptionally does in words such as departmental /2010/ /0210/ ( depártment), collectivity /20100/ /02100/ ( $\leftarrow$ colléctive) (see Dabouis (2017b)).

13. That is, excluding the datasets used in $\$ 4.3 .3$, which will be presented later in the paper.

14. The $\bar{V}$ in pinéal could also be attributed to vowel preservation from pine (see §4.3.1.1).

15. The words in (6) are the only words in Table 4 in which there is a variant pronunciation for which the change of stress pattern creates a new determining context (here, that of Luick's rule). As pointed out by an anonymous reviewer, there is stress variation for several other words in Table 4 (16 words in total). Among these words, five also display vocalic differences in the relevant vowel. For three of them, detour, harem and lichee, the variation is between a foreign free vowel and a free vowel, e.g. ['ha:ri:m] ['heər-, -əm] [(,)ha:'ri:m]. Foreign free vowels are notoriously difficult to predict and, as a consequence, it seems impossible to attribute these vocalic differences to the stress differences. Lichee also has pronunciation that is not a free vowel, ['litfi:], which could be attributed to the alternative spelling litchi, in which there is an

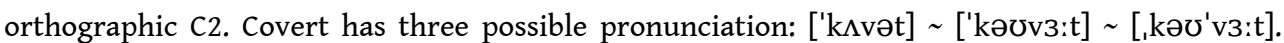
This difference can probably be attributed to different morphological interpretations, where $[\Lambda]$ would manifest the absence of morphological structure and [əひ] the recognition of the prefix co(accessible through the semantic opposition with overt or based on shared form with forms like avert, convert, divert, evert, extravert, introvert, invert, etc.). Finally, menage has several possible pronunciations, and it is surprising that the $\breve{V}$ realisation should appear with secondary stress and not with primary stress: ['meIna:3].

16. Fournier (2010: 133) asserts that this rule applies to close to 2000 words.

17. When a word has a stress variant, both instances are included in the relevant columns, e.g. egalitarian [i,gælı'teəriən] [,i:gælı'teəriən] was counted among words have a stress pattern /0201(-)/ and among the words having a $\bar{V}$ and the stress pattern /2001(-)/.

18. Bermúdez-Otero (personal communication) calls it a "crypto-compound".

19. For two of those words, the free vowel could be attributed to a related word: equal for egalitarian and (less convincingly) avian for aviation.

20. Although idea is generally pronounced as a disyllable in British English because of historical smoothing, I am assuming it is still trisyllabic based on its derivatives, ideate ['aIdieIt] and ideation [,aIdi'eIJən], in which it can be seen that the second and third syllable can still be distinct.

21. Carr (2000) argues that the same could be true for phonological analyses of English stress because Standard Scottish English has the exact same stress system and yet has no vowel length. 22. For further discussion on the issue of "stress" and "accent", see Dabouis(2016: §3.1, 2017b; Fox 2000: §3.1.1; Schane 2007; van der Hulst 2012, 2014).

23. I will not represent the prosodic structure for initial unstressed syllables because it is not relevant here. In line with Davis \& Cho (2003) and Jensen (2000), it could be assumed that such syllables are adjoined to a higher foot projection to their right, which is also necessary wordinternally to account for the aspiration and absence of flapping in American English in the third syllable of words such as Mèditerránean.

24. Note that this analysis cannot completely account for the vowel value of disyllables with initial stress. As pointed out by Deschamps (1994: 230), these words generally have $\bar{V} s$, as predicted by the present analysis, but there are many subclasses which do not. 
25. Here the angle brackets represent extrametricality.

26. There is a rule which I did not evoke in $\$ 1.2$ because it concerns disyllables only: -iC\# $\rightarrow \breve{V}$. The verbs that could owe their $\breve{V}$ to this rule have been excluded from Table 7 but, actually, if one considers the only relevant case, imagine, which should obey the rule of the penultimate, the new rule for verbs should precede the rule of the penultimate. As the rule of the penultimate itself dominates the $-\mathrm{iC} \#$ rule, then this means that verbs with -iC\# should actually be integrated within the new rule for verbs. The following words, all with $\breve{V}$ should then be integrated: merit, posit, visit, vomit, abolish, admonish, astonish, cohabit, demolish, diminish, elicit, exhibit, inhabit, inherit, inhibit, prohibit, replenish, establish, solicit. Doing so would bring the efficiency of the rule to $89 \%$.

27. [I] was coded as reduced when found in the second syllable. This was done to avoid excluding a large part of the dataset (17 words out of 85 have [I] in their second syllable) and was based on the observation that vowel reduction is extremely common in this position (see $\$ 4.3 .3$ below).

28. The stepwise derivation used here is adopted for the purposes of the demonstration. This could perfectly be achieved in a parallel derivation using constraints, as in Optimality Theory (Prince \& Smolensky 1993).

\section{ABSTRACTS}

There are few studies which have focused on the pronunciation of vowels with secondary stress in English. Within the framework introduced by Guierre (1979), this paper offers a large empirical study of these vowels and focuses on three key categories of words: non-derived words, constructions containing a semantically transparent prefix and suffixal derivatives. Overall, previous analyses based on rank, phonological domains and derivational isomorphism are confirmed but certain phenomena unveiled by this study require a few revisions of existing models. Several possible formalisation options are proposed to implement these revisions. The most promising seems to be the (here, exploratory) analysis using feet because it could considerably broaden the empirical coverage of the theory.

Peu d'études se sont concentrées sur la prononciation des voyelles sous accent secondaire en anglais. Dans le cadre de l'approche introduite par Guierre (1979), cet article propose une étude empirique large de ces voyelles et se concentre sur trois catégories clés de mots : les mots nondérivés, les constructions contenant un préfixe sémantiquement transparent et les dérivés suffixaux. Dans leur ensemble, les analyses précédentes fondées sur le rang, les domaines phonologiques et l'isomorphisme dérivationnel sont confirmées mais certains phénomènes mis à jour par cette étude rendent nécessaires quelques révisions des modèles existants. Plusieurs possibilités de formalisations sont proposées pour ces révisions, dont la plus prometteuse semble être l'analyse (ici de nature exploratoire) ayant recours aux pieds car celle-ci permettrait d'élargir considérablement la couverture empirique de la théorie.

\section{INDEX}

Keywords: English, secondary stress, phonology, reading grammar, graphophonemics

Mots-clés: Anglais, accent secondaire, phonologie, grammaire de la lecture, graphophonologie 
AUTHOR

QUENTIN DABOUIS

Université Clermont Auvergne - LRL (EA 999) 